\title{
Quick Respons Code For Futsal Teaching Materials
}

\author{
Ervin Dwi Rahayu ${ }^{1)}$, Yuskhil Mushofi ${ }^{2)}$ \\ Program studi Pendidikan Jasmani Kesehatan dan Rekreasi \\ Fakultas Pendidikan Ilmu Eksakta dan Keolahragaan \\ 1,2IKIP Budi Utomo Malang, Jawa Timur Indonesia \\ Email: ${ }^{1}$ Ervin_dr@yahoo.com, ${ }^{2}$ yuskhilgalbina@gmail.com
}

\begin{abstract}
The purpose of this research is to develop teaching materials for futsal courses that can be accessed online as material for wider study and development for Futsal courses and references for daily learning activities in class based on 2-dimensional quick response codes so that the material can be studied repeatedly - reset independently with internet access. The development model in this study refers to the stages of Borg and Gall's research. The data obtained at the validation stage by experts from 3 expert validators, namely learning media experts $76.7 \%$, learning material experts $73.6 \%$ while language experts $78 \%$. At the trial stage, the data obtained were small group trials $73.83 \%$, field tests $72.57 \%$, field tests $273.48 \%$. The conclusion of this research is that the development product in the form of teaching materials can be implemented.
\end{abstract}

Keywords: Quick Respons Code, Teaching Material, Futsal.

\section{Kode Respons Cepat Untuk Bahan Ajar Mata Kuliah Futsal ABSTRAK}

Tujuan dilakukan penelitian ini untuk mengembangkan bahan ajar mata kuliah futsal yang dapat diakses secara online sebagai bahan untuk kajian dan pengembangan lebih luas untuk mata kuliah Futsal, dan referensi untuk kegiatan pembelajaran harian di kelas yang berbasis kode respons cepat 2 dimensi sehingga materi bisa dipelajari berulang-ulang secara mandiri dengan akses internet. Model pengembangan pada penelitian ini merujuk tahapan-tahapan penelitian Borg dan Gall. Yang berjumlah 10 tahapan. Data yang diperoleh pada tahap validasi oleh ahli dari 3 validator ahli yaitu ahli media pembelajaran $76,7 \%$, ahli materi pembelajaran $73,6 \%$ sedangkan ahli bahasa 78\%. Penelitian dilakukan pada mahasiswa program studi PJKR IKIP Budi Utomo Malang angkatan 2017 yang sedang mengampuh mata kuliah futsal disemester 7. Pada tahap uji coba mengunakan pengisian angket diperoleh data yaitu uji coba kelompok kecil yang dilakukan kepada 6 mahasiswa 73,83\%, uji lapangan 72,57\% pada 30 mahasiswa, 40 mahasiswa untuk uji lapangan $273,48 \%$. kesimpulan dari penelitian ini adalah produk pengembangan berupa bahan ajar bisa diimplementasikan.

Kata Kunci: Kode Respons Cepat, Bahan Ajar, Futsal.

Info Artikel

Dikirim

Diterima

Dipublikasikan
: 29 Oktober 2020

: 8 November 2020

: 12 November 2020
(C) 2020 IKIP BUDI UTOMO MALANG

P-ISSN 2613-9421

E-ISSN 2654-8003

$\square$ Alamat korespondensi: Ervin_dr@yahoo.com

IKIP Budi Utomo Malang, Jl. Simpang Arjuno No.14B, Kauman, Kec. Klojen, Kota Malang, Jawa Timur 65119, Indonesia 


\section{PENDAHULUAN}

Meningkatkan antusiasme mahasiswa untuk belajar selalu menjadi masalah penting dalam pendidikan tinggi. Namun, dengan kemajuan teknologi, banyak siswa menjadi semakin kecanduan game seluler dan komunitas online bahkan di dalam kelas. Gangguan ini memengaruhi pembelajaran mereka dan berarti mereka tidak memperoleh bakat yang dibutuhkan oleh industri setelah lulus. Fenomena yang ada sekarang yaitu menurunnya kemampuan mahasiswa setelah menempuh pendidikan tinggi. Itulah yang akan menjadi suatu tantangan tersendiri bagi pengajar untuk bisa melahirkan pendekatan, media dan model baru untuk mengembalikan semangat belajar siswa. Menanggapi perubahan lingkungan dalam pendidikan tinggi, butuh dikembangkan media pembelajaran berbasis teknologi yang inovatif.

Tantangan bagi pendidik saat ini adalah menggunakan teknologi dalam pembelajaran. Penggunaan teknologi dalam pembelajaran niscaya akan memudahkan guru dalam mendidik siswanya. Oleh karena itu, guru membutuhkan keterampilan pedagogis dalam merancang pembelajaran dengan memanfaatkan teknologi untuk menyelesaikan masalah pembelajaran. Salah satu dari berbagai cara yang bisa diterapkan adalah prinsip-prinsip mobile learning. Pembelajaran seluler, juga dikenal sebagai m-learning, adalah cara baru untuk mengakses konten pembelajaran menggunakan perangkat seluler seperti smartphone, tablet, atau ponsel (Bahtiar \& Surjono, 2020). Telah dibuktikan melalui penelitian bahwa penggunaan perangkat seluler dalam pembelajaran dapat meningkatkan motivasi belajar, hasil belajar, dan membuat proses pembelajaran menjadi lebih menyenangkan. Siswa juga memiliki keaktifan dan kekreatifan yang lebih pada saat pembelajaran di dalam kelas sedang berlangsung bersama gurunya (Bahtiar \& Surjono, 2020).

Seperti yang dikemukakan oleh Januszewski dan Molenda yang dikutip (Situmorang, Lagun, Ibrahim, \& Lagunsiang, 2019), permasalahan teknologi pendidikan untuk menyelesaikan masalah pembelajaran didasarkan pada seperangkat prinsip dan menggunakan pendekatan yang beragam. Sesuai dengan pendapat Januszewski dan Molenda (Situmorang et al., 2019) Teknologi pendidikan merupakan kegiatan yang meliputi studi dan praktik etis untuk 
memberikan fasilitas pada proses pembelajaran dan peningkatan kinerja dengan cara diciptakan, digunakan, dan dikelola proses dan sumber daya teknologi.

Huah dan Jaret yang dikutip (Yunus, Yen, Yen, Khair, \& Yusof, 2020) mengungkapkan bahwa Kode Respons Cepat (QR) adalah teknologi serbaguna dalam hal menghasilkan lingkungan belajar terpandu, namun tetap memungkinkan pelajar untuk menyelam dalam proses pembelajaran. Kebebasan ini memberi siswa untuk melakukan navigasi pembelajaran dengan kecepatan mereka sendiri. Kode Respons Cepat (QR) digunakan untuk menghubungkan analog ke dunia digital sejajar dengan lingkungan belajar dimanapun kita berada untuk memenuhi kebutuhan dan gaya belajar yang berbeda dari pelajar abad ke-21. Akses cepat ke berbagai informasi berguna (tautan situs web dan video yang terhubung ke kode) menghemat banyak waktu siswa, sehingga meningkatkan produktivitas belajar mereka (Nazleen, Rabu, Hussin, \& Bervell, 2018).

Kode Respons Cepat (QR) adalah sepotong teks panjang yang berisi multibahasa, URL yang ditautkan, pesan SMS otomatis, kartu nama atau hampir semua informasi dapat disematkan ke dalam kode batang dua dimensi (Law \& Law, 2010). Ditambah dengan perangkat seluler yang dilengkapi dengan moderat, Kode Respons Cepat (QR) dapat menghubungkan pengguna ke informasi dengan cepat dan mudah. Hambatan teknis yang rendah dalam membuat dan membaca Kode Respons Cepat (QR) memungkinkan pendidik yang inovatif untuk memasukkannya ke dalam upaya peningkatan proses pendidikan. Usaha untuk mengambil atau menyimpan Kode Respons Cepat (QR) sangat sederhana dan cepat, dan dengan perangkat seluler, menjadikannya alat pendidikan yang ideal untuk pengajaran dan pembelajaran. Melalui media ponsel yang dipakai, dapat mengakses Situs Web yang telah teratur dengan alamat website yang dituju dengan kecepatan tinggi, kita dapat secara langsung melakukan pengiriman pesan SMS atau kita mendapatkan kemudahan untuk melakukan penyimpanan informasi kontak ke buku alamat. Dengan menggunakan perangkat seluler dengan perangkat lunak decoding untuk memindai $Q R$ Code, pengguna dapat dialihkan melalui Internet ke platform informasi digital yang berisi materi audiovisual dan panduan audio (Lai, Chang, Li, Fan, \& Wu, 2013).

"QR" adalah singkatan dari "Respons Cepat." QR dapat dibaca dengan 
posel yang sudah memiliki fitur seperti kamera dan pemindai QR. Spesifikasinya adalah ISO/IEC 18004: 2000 \& 2006 dan JIS X 0510 yang dapat dibentuk dan memiliki sebuah daya tampung data yang tidak bisa dianggap remeh di dalam ukuran cetakan yang tidak terlalu besar dan utilitas dalam memindai dengan kecepatan tinggi menggunakan perangkat seluler sudah tersedia. $Q R$ code adalah gambar digital optikal yang dikenali oleh decoder, diterapkan secara luas pada semua jalur kehidupan demi kecepatan membaca yang cepat, kepadatan data yang tinggi, dan kemampuan koreksi kesalahan yang kuat (Fu, Liu, Sun, Fang, \& Yu, 2020).

Kode Respons Cepat (QR) menyimpan 7.089 karakter dalam bentuk nomor, 4.296 karakter huruf dan angka yang digabungkan, 2.953 byte biner, 1.817 karakter huruf yang berasal dari China atau percampurannya. Kemampuan daya tampung datanya jauh diatas kode 2D lainnya seperti PDF417, Data Matrix dan Maxi Code (Chen, Hsiao, Kang, \& Wu, 2020). Ini menyimpan informasi baik dalam arah vertikal maupun horizontal. Kode Respons Cepat (QR) dengan sangat mudah terbaca dari berbagai arah menggunakan pola deteksi posisi yang ada pada tiga sudut dapat dibaca meskipun agak terdistorsi oleh kemiringan atau pada permukaan yang melengkung oleh pola penyelarasan dan pola waktu. Kesalahan pada kemampuan koreksi terhadap kesalahan dan kerusakan bisa sampai $30 \%$. Fungsionalitas penautan dimungkinkan untuk Kode Respons Cepat (QR) diwakili hingga maksimal 16 Kode Respons Cepat (QR) sehingga ruang pencetakan kecil dimungkinkan. Ukuran Kode Respons Cepat (QR) dapat bervariasi dari 21x21 sel hingga 177x177 sel dengan peningkatan 4 sel baik secara horizontal maupun dan arah vertikal.

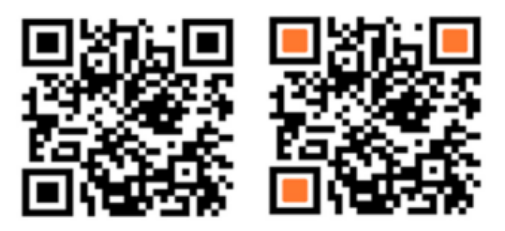

Gambar 1. Matrik Qr Code

Banyak penelitian yang sudah dilakukan oleh para peneliti lain guna untuk menerapkan Kode Respons Cepat (QR) didalam proses pembelajaran yaitu (Akhbar, 2018) booklet yang digunakan untuk mata pelajaran sejarah, (Afdal, Irsyad, \& Yanto, 2018) materi lapisan permukaan bumi, bahan ajar untuk mata 
kuliah microbiologi (Smith, Segura-totten, \& West, 2018), (Firmansyah \& Hariyanto, 2019a) pada bahan ajar untuk mata kuliah organisasi dan sistem pertandingan, (Marcus \& Bempah, 2019) penggunan pada pembelajaran keperawatan, (Firmansyah \& Hariyanto, 2019b) bahan ajar matakuliah teori dan praktek tenis meja, (Brodie, Madden, \& Rosen, 2020) pembelajaran medis. Sedangkan pada bidang lain Kode Respons Cepat (QR) juga sudah digunakan untuk berbagai kebutuhan seperti pelabelan aset (Ariska \& Jazman, 2016), manajemen presensi rapat (Ardiansyah \& Fendina, 2016), penyusunan KRS dan KHS (Rochman, Raharjana, \& Taufik, 2017), buku saku yang digunakan melalui telepon (Setiadi et al., 2019) .

Dari berbagai penelitian diatas belum ditemukan penggunaan Kode respons Cepat (QR) pada mata kuliah Futsal sehingga peneliti ingin mengembangkan bahan ajar mata kuliah futsal berbasis kode respons cepat 2 dimensi yang bisa diakses secara online sebagai bahan untuk kajian dan pengembangan lebih luas untuk mata kuliah Futsal dan referensi untuk kegiatan pembelajaran harian di kelas. Bahan ajar yang berisi tentang sejarah futsal, teknik dasar futsal, posisi pemain futsal, formasi tim, peraturan permainan futsal yang dilengkapi dengan Kode Respons Cepat (QR) 2 dimensi sehingga materi bisa dipelajari berulang-ulang secara mandiri dengan akses internet.

\section{METODE}

Model penelitian pengembangan yang digunakan sebagai rujukan yaitu model pengembangan (research and development) Borg dan Gall yang dikutip (Suharnoko \& Firmansyah, 2018). Penelitian dilakukan pada mahasiswa program studi PJKR IKIP Budi Utomo Malang angkatan 2017 yang sedang mengampuh mata kuliah futsal di semester 7. Tahapan penelitian pengembangan diantaranya 1) Analisis kebutuhan (need assessment), melalui penyebaran angket pada 2 dosen mata kuliah futsal dan 30 mahasiswa, 2) Perencanaan membuat produk awal bahan ajar mata kuliah futsal, 3) mengembangkan produk bahan ajar awal berdasarkan dari hasil analisis kebutuhan, 4) Persiapan uji coba kelompok kecil dengan cara produk awal yang telah terbentuk divalidasikan kepada 2 orang ahli materi futsal dan 1 ahli bahasa. Selanjutnya, produk yang sudah divalidasi oleh 
para ahli direvisi tahap pertama. Lalu dilakukan uji coba lapangan kepada 6 subjek, dari 3 kelas masing-masing 2 subjek, 5) Melakukan perbaikan produk hasil uji coba dan menyempurnakan produk sesuai hasil yang diperoleh, 6) Uji coba Lapangan dilakukan pada mahasiswa dengan melibatkan 30 subyek uji coba, 7) melakukan perbaikan dan penyempurnaan sesuai dengan hasil yang dikumpulkan dari uji coba lapangan, 8) Uji coba Lapangan dilakukan pada mahasiswa dengan melibatkan subyek uji coba lebih luas 40 subjek, 9) Penyempurnaan produk hasil yang didapat dari uji coba lapangan berdasarkan hasil dari uji coba lapangan, 10) Langkah terakhir adalah diseminasi dan implementasi produk yang terdiri dari beberapa langkah yaitu menulis laporan dan penyebarluasan produk kepada mahasiswa.

Pada penelitian ini instrumen pengumpulan data menggunakan beberapa teknik antara lain: angket kuisioner analisis kebutuhan, lembar validasi ahli dan uji coba. Proses analisis ini dimulai dengan pengelompokan dan deskripsi informasi dalam bentuk kualitatif yang didapatkan dari lembar angket validasi para ahli maupun angket yang sudah disebarkan dan diisi oleh mahasiswa. Analisis deskriptif adalah analisis yang berfungsi dalam proses pengolahan data yang sudah dikumpulkan. Selanjutnya data akan dirubah dalam bentuk lain yaitu bentuk persen rumus yang digunakan yaitu rumus pesrentase Sugiyono (Suharnoko \& Firmansyah, 2018) sebagai berikut

$$
\mathbf{P}=(\mathrm{F} / \mathrm{N}) \mathbf{X} 100 \%
$$

Keterangan :

$\mathrm{f}$ : Ukuran jumlah yang ingin diketahui prosentasenya

$\mathrm{N}$ : jumlah banyaknya ukuran jumlah

P : Angka rasio yang didapat

Tabel 1. Kategori Kelayakan Produk

\begin{tabular}{ccc}
\hline Kategori & Persentase & Keterangan \\
\hline Baik & $76 \%-100 \%$ & Digunakan \\
\hline Cukup & $56 \%-75 \%$ & Digunakan \\
\hline Kurang Baik & $40 \%-55 \%$ & Tidak digunakan \\
\hline Tidak baik & Kurang dari $40 \%$ & Tidak digunakan \\
\hline
\end{tabular}




\section{HASIL DAN PEMBAHASAN}

Hasil penelitian pada proses pengumpulan data yang dilakukan oleh para validator ahli yaitu 1 orang ahli bahasa, ahli perminan futsal dan ahli media pembelajaran, uji coba pada kelompok kecil dan uji coba lapangan tersaji pada gambar dibawah ini :

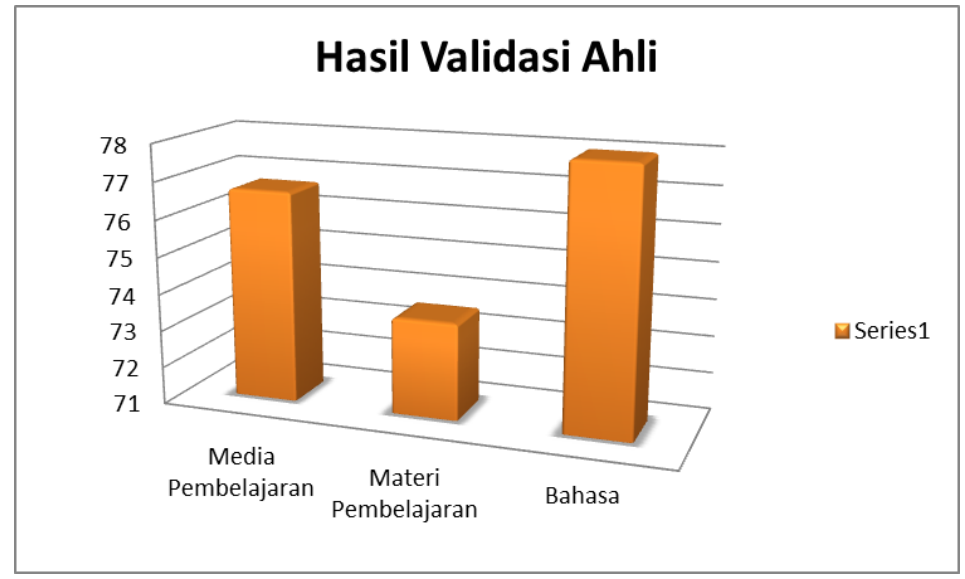

Gambar 2. Hasil Validasi Ahli

Tahap validasi ahli yang dilakukan oleh 3 orang validator ahli secara rinci bisa diketahui data yang terkumpul sesuai dengan tabel diatas yaitu ahli media pembelajaran $76,7 \%$, ahli materi pembelajaran $73,6 \%$ sedangkan ahli bahasa $78 \%$.

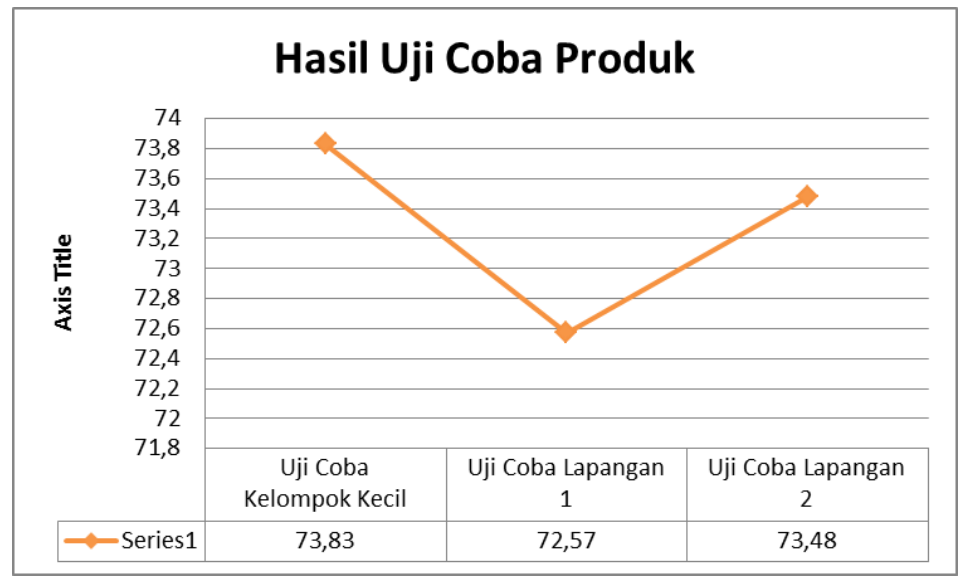

Gambar 3. Hasil Uji Coba Produk

Tabel diatas menyajikan data yang diperoleh pada tahapan uji coba produk yakni uji coba pada kelompok kecil data yang diperoleh $73,83 \%$, data uji coba 
lapangan 1 sebesar 72,57 \% dan uji coba lapangan 2 data yang didapatkan 73,48 $\%$.

Sesuai dengan ketentuan yang dikeluarkan oleh Depdiknas (Nasruddin, 2020), materi-materi pembelajaran terdiri dari 3 unsur utama yaitu pengetahuan atau kognitif, keterampilan dalam kata lain psikomotor dan afektif atau sikap yang harus menjadi satu kesatuan untuk dipelajari agar standar kompetensi bisa dicapai. Pannen dan Purwanto (Magdalena, Sundari, Nurkamilah, Amalia, \& Tangerang, 2020) mengungkapkan bahwa jika bahan ajar yang disusun melalui tahap perancangan dan pengembangan yang sesuai berdasarkan prinsip-prinsip instruksi pembelajaran yang baik dan benar maka akan menjadi salah satu bantuan bagi mahasiswa dalam mendukung lancarnya proses belajarnya, kerja dosen untuk melakukan pengurangan waktu untuk penyampaian materi dan memperbanyak waktu bimbingan dosen bagi mahasiswa lebih mudah dan luwes, membantu perguruan tinggi dalam menyelesaikan kurikulum dan mencapai tujuan instruksional dengan waktu yang tersedia. Dari kedua pengertian tersebut bahwa materi pembelajaran adalah sebuah perangkat materi yang disusun secara sistematis yang digunakan untuk menciptakan lingkungan belajar.

Penggunaan Kode respons Cepat (QR) sudah terbukti efektif sebagai salah satu media yang memberikan dampak yang positif karena siswa yang mendapatkan pembelajaran menggunakan QR pemahaman konsepnya lebih baik dari pada pembelajaran yang normal pada umumnya (Auliya \& Munasiah, 2018), lebih jauh lagi seperti hasil penelitian (Firmansyah, Hariyanto, \& Kurniawan, 2019) penggunaan $Q R$ pada bahan ajar untuk mata kuliah teori dan praktek tenis meja memberikan sumbangan yang positif pada motivasi mahasiswa untuk belajar dan peningkatan teknik dasar dalam permainan tenis meja. menurut (Ataji \& Sujarwanta, 2020) yang dituliskan pada hasil penelitiannya bahwa salah satu media pembelajaran yang layak digunakan pada proses pembelajaran yaitu QR.

Berikut beberapa fungsi dari bahan ajar adalah: 1) sebagai pedoman guru yang akan mengarahkan semua aktivitas dalam proses pembelajaran, sekaligus merupakan substansi kompetensi yang seharusnya diajarkan pada pembelajaran, 2) pedoman bagi siswa yang akan mengarahkan aktivitasnya dalam proses pembelajaran, sekaligus merupakan substansi kompetensi yang seharusnya 
dikuasainya, 3) sebagai alat evaluasi pencapaian/penugasan hasil belajar Depdiknas (Nasruddin, 2020). Penggunaan bahan ajar dapat membantu pembelajar untuk secara mendalam melakukan kajian suatu kompetensi secara runtut dan sistematis sehingga mampu menguasai suatu kompetensi secara utuh. Menurut Igfir Rijal (Nasruddin, 2020), tidak dipungkiri bahwa pembelajaran juga membutuhkan suatu bahan ajar yang orientasinya pada model pembelajaran yang mengarah pada pertumbuhan minat siswa dan menuntun siswa untuk merampungkan suatu masalah melalui sebuah hasil karya. Pengembangan bahan ajar ini memiliki strategi sebagaimana Degeng (Ita \& Putra, 2020) menyatakan bahwa strategi pembelajaran diartikan sebagai penataan cara, sehingga terwujudnya suatu urutan langkah prosedural yang dapat digunakan untuk mencapai hasil pembelajaran yang diinginkan.

\section{SIMPULAN}

Data yang terkumpul kemudian dianalisis pada tahapan validasi ahli dan uji coba maka kesimpulan yang dapat ditarik yaitu bahan ajar mata kuliah futsal berbasis kode respons cepat dapat diimplementasikan setelah melakukan beberapa perbaikan sesuai arahan dan masukan yang diberikan.

Secara umum, peneliti mempercayai bahwa kode respons cepat mempunyai potensi besar dalam bidang pendidikan. Beberapa kemungkinan untuk pengembangan lebih lanjut pada artikel ini sudah dijelaskan dan ada banyak ide kreatif menunggu untuk menjelajah lebih dalam. Selain itu, artikel ini dapat menjadi langkah pertama bagi pembaca untuk menyelidiki topik media pembelajaran berbasis kode respons cepat yang menarik ini.

\section{DAFTAR RUJUKAN}

Afdal, M., Irsyad, M., \& Yanto, F. (2018). Penerapan Teknologi Augmented Reality Pada Media Pembelajaran Lapisan Permukaan Bumi Berbasis 3d. Jurnal Ilmiah Rekayasa Dan Manajemen Sistem Informasi, 4(1), 1-10.

Akhbar, G. W. O. (2018). Pengembangan Bahan Ajar Booklet Berbasis Qr Code Dalam Pembelajaran Sejarah Dengan Materi Pertempuran Trip Malang Sebagai Upaya Mempertahankan Kemerdekaan Indonesia Untuk Kelas Xi Jasa Boga 2 Di Smkn 1 Batu. Universitas Negeri Malang.

Ardiansyah, \& Fendina, G. P. P. (2016). Pengembangan Sistem Manajemen 
Presensi Rapat Berbasis Qr Code Pada Android. In Konferensi Nasional Teknologi Informasi Dan Aplikasinya (Pp. 5-56).

Ariska, J., \& Jazman, M. (2016). Rancang Bangun Sistem Informasi Manajemen Aset Sekolah Menggunakan Teknik Labelling Qr Code (Studi Kasus: Man 2 Model Pekanbaru). Jurnal Rekayasa Dan Manajemen Sistem Informasi, 2(2), 127-136.

Ataji, H. M. K., \& Sujarwanta, A. (2020). Analisis Pentingnya Pengembangan Modul Berbasis Video Assistant Menggunakan Link Qr Code Tentegrasi Alquran Dan Hadis Materi Sma Sistem Reproduksi Manusia. Biolova, 1(1), $48-55$.

Auliya, R. N., \& Munasiah. (2018). Efektivitas Augmented Reality Dengan Qr Code Dalam Pembelajaran Geometri 3d. Unes Journal Of Education Scienties, 2(2), 127-132.

Bahtiar, A. Z., \& Surjono, H. D. (2020). Teacher And Student Perspective Of Using The Quick Response Code Feature In The Biology Module. In International Conference On Online And Blended Learning 2019 (Icobl 2019) Teacher (Vol. 440, Pp. 201-206).

Brodie, K., Madden, L. L., \& Rosen, C. A. (2020). Applications Of Quick Response (Qr) Codes In Medical Education. Journal Of Graduate Medical Education, 12(2), 138-140.

Chen, T., Hsiao, T., Kang, T., \& Wu, T. (2020). Learning Programming Language In Higher Education For Sustainable Development : Point-Earning Bidding Method. Sustainability, 12(11), 1-14.

Firmansyah, G., \& Hariyanto, D. (2019a). Qr Code Based Teaching Materials For Organizational Classes And Game Systems. Journal Of Physical Education, Health And Sport, 6(1), 6-10.

Firmansyah, G., \& Hariyanto, D. (2019b). The Use Of Qr Code On Educational Domain: A Research And Development On Teaching Material Guntur. Jurnal Sportif: Jurnal Penelitian Pembelajaran, 5(2), 284-297.

Firmansyah, G., Hariyanto, D., \& Kurniawan, R. (2019). Pengaruh Bahan Ajar Berbasis Qr Code Terhadap Motivasi Belajar Dan Keterampilan Dasar Bermain Tenis Meja. In Prosiding Seminar Nasional Iptek Olahraga (Pp. 29-31).

Fu, Z., Liu, S., Sun, R., Fang, L., \& Yu, B. (2020). Distributed Color Qr Code With High-Capability And Fast Decoding. Multimedia Tools And Applications, 79(November), 32471-32485.

Ita, S., Ibrahim, I., \& Putra, M. F. (2020). Pelatihan Penerapan Program Statistical Product for Service Solution (SPSS) untuk Data Keolahragaan. Jurnal Gema Ngabdi, 2(1), 12-17. 
Lai, H., Chang, C., Li, W., Fan, Y., \& Wu, Y. (2013). The Implementation Of Mobile Learning In Outdoor Education: Application Of Qr Codes. British Journal Of Educational Technology, 44(2), 57-62. Https://Doi.Org/10.1111/J.1467-8535.2012.01343.X

Law, C., \& Law, C. (2010). Qr Codes In Education. Journal Of Educational Technology Development And Exchange (Jetde), 3(1), 85-100. Https://Doi.Org/10.18785/Jetde.0301.07

Magdalena, I., Sundari, T., Nurkamilah, S., Amalia, D. A., \& Tangerang, U. M. (2020). Analisis Bahan Ajar. Nusantara: Jurnal Pendidikan Dan Ilmu Sosial, 2(2), 311-326.

Marcus, J., \& Bempah, J. (2019). Use Of Quick Response Codes For Postpartum Hemorrhage Simulation In Nursing Education. Journal Of Obstetric, Gynecologic, \& Neonatal Nursing, 48(3), $\quad$ S57. Https://Doi.Org/10.1016/J.Jogn.2019.04.098

Nasruddin. (2020). Pengembangan Bahan Ajar Sejarah Daerah Bima Berbantu Quick Response Codes Kelas X Sma Negeri 1 Woha. Jurnal Ilmu Sosial Dan Pendidikan, 4(3), 26-31.

Nazleen, S., Rabu, A., Hussin, H., \& Bervell, B. (2018). Qr Code Utilization In A Large Classroom: Higher Education Students ' Initial Perceptions. Education And Information Technologies, 24(1), 359-384.

Rochman, F. F., Raharjana, I. K., \& Taufik, T. (2017). Implementation Of Qr Code And Digital Signature To Determine The Validity Of Krs And Khs Documents. Scientific Journal Of Informatics, 4(1), 8. Https://Doi.Org/10.15294/Sji.V4i1.7198

Setiadi, B. R., Subagyo, Johan, A. B., Nurtanto, M., Sugiyono, \& Nurdiyanto, H. (2019). Mobile Pocketbook Of The 4cs Skills-Oriented Inform Of Quick Response Code. In Proceedings Of The International Conference Of Social Science. Https://Doi.Org/10.4108/Eai.21-9-2018.2281182

Situmorang, R., Lagun, J., Ibrahim, N., \& Lagunsiang, J. (2019). Development Of Collaborative Learning Materials Based On Qr Code To Facilitate Learning. International Journal Of Innovation, Creativity And Change, 8(6), 85-98.

Smith, M., Segura-Totten, M., \& West, K. (2018). Curriculum Qr Code Lecture Activity As A Tool For Increasing Nonmajors Biology Students' Enjoyment Of Interaction With Their Local Environment $\uparrow$. Journal Of Microbiology \& Biology Education, 19(1), 1-6.

Suharnoko, F., \& Firmansyah, G. (2018). Pengembangan Model Pembelajaran Melompat Melalui Permainan Lompat Cermin Untuk Siswa Sekolah Dasar. Jurnal Sportif : Jurnal Penelitian Pembelajaran, 4(2), 145-158.

Yunus, M. M., Yen, E. L., Yen, Khair, A. H. M., \& Yusof, N. M. (2020). Acquisition Of Vocabulary In Primary Schools Via Gopic With Qr Code. 
194 Ervin Dwi Rahayu ${ }^{1}$, Yuskhil Mushofi ${ }^{2}$. Jp.jok (Jurnal Pendidikan. Jasmani, Olahraga dan Kesehatan). 4(1) 183-194

International Journal Of English Language And Literature Studies, 9(3), 121-131. Https://Doi.Org/10.18488/Journal.23.2020.93.121.131 